\title{
CONTRIBUTIONS TO THE BRYOPHYTE FLORA OF THE MAVROVO NATIONAL PARK (REPUBLIC OF MACEDONIA)
}

\author{
Beáta PAPP ${ }^{1 *}$, Erzsébet SzURdoki ${ }^{1}$, Jovana PANTović ${ }^{2}$ and \\ Marko SABovljević ${ }^{2}$ \\ ${ }^{1}$ Department of Botany, Hungarian Natural History Museum \\ H-1431, Budapest,Pf. 137, Hungary; *papp.beata@nhmus.hu \\ ${ }_{2}^{2}$ Institute of Botany and Botanical Garden, Faculty of Biology, University of Belgrade \\ 11000 Belgrade, Serbia
}

Papp, B., Szurdoki, E., Pantović, J. \& Sabovljević, M. (2016): Contributions to the bryophyte flora of the Mavrovo National Park (Republic of Macedonia). - Studia bot. hung. 47(2): 279-296.

\begin{abstract}
Mavrovo National Park (Republic of Macedonia). Almost all habitat types maintain diverse bryophyte assemblages containing several species rare on the Balkans or even species of European conservation interest. Three species found (Buxbaumia viridis, Grimmia caespiticia, and Pseudoleskea saviana) are included in the Red data book of European bryophytes. Further eight species are on the candidate list of the new Red data book of European bryophytes and ten species can be regarded as rare on the Balkans.
\end{abstract}

Key words: European red-listed species, liverworts, mosses, rare bryophytes, the Balkans

\section{INTRODUCTION}

The Republic of Macedonia is one of the bryologically poorly explored countries in SE Europe (SABOVLJEVIĆ et al. 2001, 2011). Data on the bryophyte flora of the Republic of Macedonia can be found in DüLL et al. (1999), CEKOVA (2005), in the checklists of the SE European and Mediterranean countries (SABovljević and Natcheva 2006, Sabovljević et al. 2008, Ros et al. 2007, 2013), in MARTinčič (2009), PAPP et al. (2011), and PAPP and Erzberger (2012). Even short field trips added a lot of new species to the Macedonian bryophyte flora, e.g. 12 new national records (9 liverworts and 3 mosses) during a 2-day trip (PAPP et al. 2011), 43 (10 liverworts, 33 mosses) during a 7-day trip (PApp and Erzberger 2012). According to Hodgetts (2015) the Macedonian bryophyte flora consists of 546 taxa ( 99 hepatics and 447 mosses). Recently, further 27 bryophyte species ( 7 hepatics and 20 mosses) have been reported for the first time in the Macedonian bryophyte flora from the Mavrovo National Park (PAPP et al. 2016). The number of the known bryophyte taxa from the country is 
still about 200-250 less than that of the neighbouring countries (Bulgaria: 807, Greece: 723, Serbia: 723) (HodgetTs 2015). Only Albania has lower number of bryophyte taxa (466) according to HodgetTs (2015), which is due to the underexplored bryoflora of this country, too. On the other hand many bryophytes have only one or two records from the Republic of Macedonia, hence there is not enough knowledge to evaluate the threat status of species or to establish a list of important bryophytes from conservation point of view.

With this paper we would like to contribute in the exploration and conservation of the Macedonian bryoflora giving an overview about the bryophyte vegetation of the Mavrovo National Park with special attention to the species of conservation interest.

\section{MATERIAL AND METHODS}

\section{Study area}

The Mavrovo National Park is situated in the northwestern part of the Republic of Macedonia (Fig. 1). It has been founded in 1948, and covers an area of 73,088 hectares including the Korab, Desat, Šara, Bistra and Krčin mountains, the valley of the river Radika and its tributaries and the lake Mavrovo (BUZAROvs KI 2009).

The area of the Mavrovo National Park represents specific physical-geographic and orographic conditions, related with the altitude. Thus, in its territory various climate types can be recorded; from warm continental climate to alpine climate.

The Mavrovo National Park belongs to the Western Macedonian Geotectonic Unit. The bedrocks, which are of various age and mineralogical structure, could be grouped into three geological formations: Paleozoic metamorphic and volcanic rocks, Mesozoic limestone rocks, and Quaternary slates (http://npmavrovo. org.mk/киима-2).

Altogether 86 mountain peaks higher than 2,000 m are situated within the boundaries of the national park. The other most significant relief formations are the river beds with canyons and caves. For instance, within the Radika River watershed, altogether 16 canyons and 42 caves are known. The whole territory of the protected area of the national park basically is included in the watershed of the Radika River. The total length of the Radika River course is $64.7 \mathrm{~km}$ and its watershed encompasses an area of $879.8 \mathrm{~km}^{2}$. Besides the rivers and streams other hydrological formations are also present: springs, glacial lakes, temporary pools, and the reservoir-lake Mavrovsko Ezero (Mavrovo lake) (http://npmavrovo.org.mk/хидрологија-и-хидрографија). 


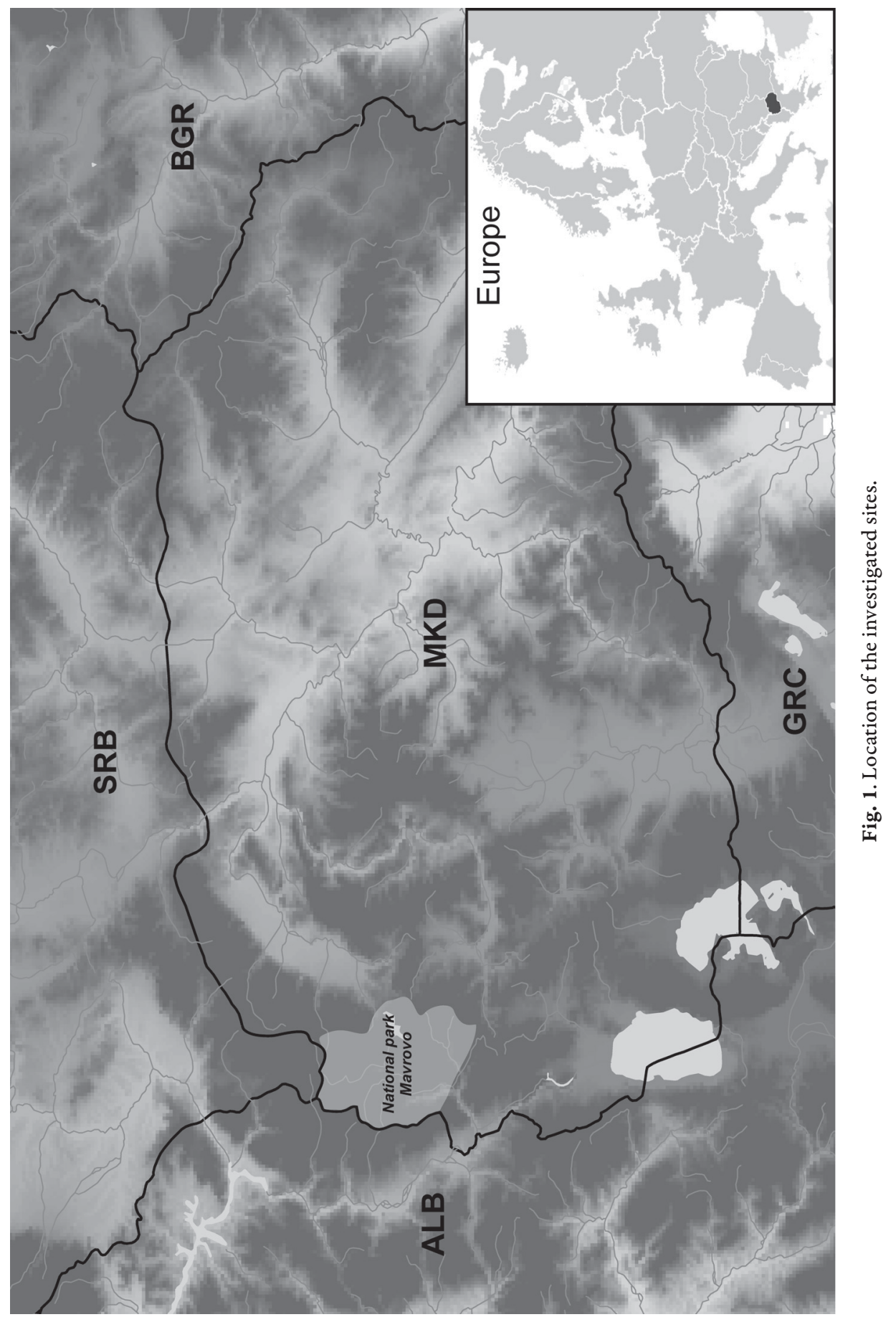


The Mavrovo National Park has high species diversity. For instance, it has a rich flora of vascular plants, with over 1,400 species recorded up to date. Many of these taxa are rare boreal and arctic-montane elements, and many are rare or endemic in the Republic of Macedonia. Floral and faunal elements with PontoMediterranean (Eastern Mediterranean) biogeographic origin are predominant, followed by the species with boreal and arctic-montane origin, of which the relict-mountain entities are frequent and abundant (http://npmavrovo.org.mk/ инвертебратна-фауна).

\section{Methods}

Our collecting trips were made in June 2013 and July 2014. All main habitat types, such as wetlands, streams and riverbanks, calcareous and siliceous rock formations, grasslands and forests were investigated, and bryophytes collected from different substrates (soil, exposed and shaded rocks, tree bark, and decaying wood).

The specimens are preserved in the Herbarium of the Hungarian Natural History Museum, Budapest (BP) and Belgrade University Herbarium (BEOU). Nomenclature follows GroLLE and LoNG (2000) for liverworts with the exception of Conocephalum salebrosum, which follows SZWEY KOWS K et al. (2005), and Hill et al. (2006) for mosses, except for Polytrichum commune var. perigoniale, in which case KOPERSKI et al. (2000) is followed. European distribution of the species is given according to DÜLL $(1983,1984,1985)$.

\section{Site details in the Mavrovo National Park}

1. In Mavrovo village, $41.650833^{\circ} \mathrm{N}, 20.735611^{\circ} \mathrm{E}, 1,265 \mathrm{~m}, 16.06 .2013$.

2. Between Mavrovo and Galičnik villages, $41.643278^{\circ} \mathrm{N}, 20.699^{\circ} \mathrm{E}, 1,690 \mathrm{~m}, 17.06 .2013$.

3. In Galičnik village, $41.591472^{\circ} \mathrm{N}, 20.64725^{\circ} \mathrm{E}, 1,710 \mathrm{~m}, 17.06 .2013$.

4. Between Mavrovo and Galičnik villages, $41.612833^{\circ} \mathrm{N}, 20.679194^{\circ} \mathrm{E}, 1,620 \mathrm{~m}, 17.06 .2013$.

5. Between Mavrovo and Galičnik villages, $41.647806^{\circ} \mathrm{N}, 20.704639^{\circ} \mathrm{E}, 1,670 \mathrm{~m}, 17.06 .2013$.

6. Towards Debar, at Mavrovska River along the road to Sveti Petka, $41.735194^{\circ} \mathrm{N}, 20.671778^{\circ} \mathrm{E}$, $965 \mathrm{~m}, 18.06 .2013$.

7. Towards Debar, at Mavrovska River along the road to Sveti Petka, $41.728583^{\circ} \mathrm{N}, 20.673028^{\circ} \mathrm{E}$, $965 \mathrm{~m}, 18.06 .2013$.

8. Towards Debar, junction of Radika River and Mavrovska River, $41.723361^{\circ} \mathrm{N}, 20.670389^{\circ} \mathrm{E}$, $925 \mathrm{~m}, 18.06 .2013$.

9. Towards Debar, along Radika River at the road to Nistrovo, $41.712917^{\circ} \mathrm{N}, 20.657694^{\circ} \mathrm{E}, 905$ $\mathrm{m}, 18.06 .2013$.

10. Towards Debar, Abieto-Fagetum forest at the dam, $41.701306^{\circ} \mathrm{N}, 20.735111^{\circ} \mathrm{E}, 890 \mathrm{~m}$, 18.06.2013.

11. Towards Galičnik village, at Toni voda meadows on the way to Lazaropole village, $41.636222^{\circ}$ $\mathrm{N}, 20.708639^{\circ} \mathrm{E}, 1,690 \mathrm{~m}, 03.07 .2014$.

12. From Toni voda meadows to Lazaropole village, $41.633083^{\circ} \mathrm{N}, 20.718083^{\circ} \mathrm{E}, 1,670 \mathrm{~m}$, 03.07.2014. 
13. From Toni voda meadows to Lazaropole village, $41.625139^{\circ} \mathrm{N}, 20.72625^{\circ} \mathrm{E}, 1,720 \mathrm{~m}, 03.07 .2014$.

14. From Toni voda meadows to Lazaropole village, around Solumnica, $41.581278^{\circ} \mathrm{N}, 20.805611^{\circ}$ E, $1,850 \mathrm{~m}, 03.07 .2014$.

15. Rostusha village, Duf canyon, $41.607639^{\circ} \mathrm{N}, 20.600861^{\circ} \mathrm{E}, 800 \mathrm{~m}, 04.07 .2014$.

16. Rostusha village, Duf canyon, around the waterfall, $41.603167^{\circ} \mathrm{N}, 20.597889^{\circ} \mathrm{E}, 800 \mathrm{~m}$, 04.07.2014.

17. In Rostusha village, $41.610611^{\circ} \mathrm{N}, 20.599194^{\circ} \mathrm{E}, 820 \mathrm{~m}, 04.07 .2014$.

18. In Mavrovo village, $41.649944^{\circ} \mathrm{N}, 20.736528^{\circ} \mathrm{E}, 1,240 \mathrm{~m}, 04.07 .2014$.

\section{RESULTS AND DISCUSSION}

229 bryophyte taxa ( 34 liverworts and 195 mosses) were recorded in the Mavrovo National Park. The complete list of the species can be found in the Appendix.

Bryophyte vegetation and its conservation merit

Wetlands

In the wetlands above $1,500 \mathrm{~m}$ a.s.l. several boreal, subboreal species are characteristic, e.g. Scapania irrigua, Aulacomnium palustre, Brachythecium rivulare, Bryum schleicheri, Calliergon cordifolium, Campylium stellatum, Climacium dendroides, Dichodontium palustre, Philonotis caespitosa, Ph. fontana, Ph. seriata, Plagiomnium elatum, P. ellipticum, Polytrichum commune var. commune, P. commune var. perigoniale, Scorpidium cossonii, Warnstorfia exannulata. Some of these above mentioned species can be regarded as rare on the Balkans and red-listed in many SE European countries (HodgetTs 2015), like Dichodontium palustre, Philonotis caespitosa, Plagiomnium ellipticum, Scorpidium cossonii. The subarctic-subalpine Palustriella decipiens can also be mentioned here. Besides these a sub-Atlantic, sub-Mediterranean species of European conservation interest (being on the candidate list of the new Red data Book of European bryophytes) (HodgetTs 2015), Fontinalis hypnoides, was also collected in a rivulet crossing the wet meadows of Toni voda. Another species of European conservation interest found here is Bryum turbinatum, a species of temperate zone of Europe.

\section{Rivers, streams}

Along Radika River and its tributaries mainly calcicole aquatic, riparian species occur, like the boreal-subboreal Gymnostomum aeruginosum, Hygrohypnum luridum, Poblia wablenbergii, the temperate Conocephalum salebrosum, Jungermannia atrovirens, Pellia endiviifolia, Cratoneuron filicinum, Didymodon sinuosus, Palustriella commutata, Platyhypnidium riparioides, the sub-Mediterranean, sub- 
Atlantic Cinclidotus fontinaloides, Didymodon spadiceus, Orthotrichum cupulatum var. riparium, Rhynchostegiella curviseta.

Further calcicole sub-Mediterranean, sub-Atlantic species appear on wet limestone rocks at a source area, e.g. Cololejeunea rossettiana, Eucladium verticillatum, Gymnostomum calcareum, Gyroweisia tenuis. On a wet siliceous rock a species of European conservation interest (HodgetTs 2015), Bryum mildeanum, was found and it was its first record in the Republic of Macedonia (PAPP et al. 2016).

\section{Limestone alpine grasslands}

Limestone bedrock is frequent in the region, but siliceous outcrops also occur. On limestone rocky places, in grasslands above $1,200 \mathrm{~m}$ a.s.l. several boreal species can be found. e.g. Preissia quadrata, Barbilophozia lycopodioides, Scapania calcicola, Ditrichum gracile, Bartramia ithyphylla, Bryum elegans, Distichium capillaceum, Pseudoleskea incurvata, Pseudoleskeella catenulata, Sanionia uncinata. Besides them, subarctic, subalpine liverworts also appear, which are rare on the Balkans lacking or being red-listed in many SE European countries (HoDGETTS 2015), like Athalamia hyalina and Leiocolea heterocolpos. Subarctic, subalpine mosses as Encalypta rhaptocarpa, Ptychodium plicatum, Syntrichia norvegica, and a northern subcontinental, dealpine element, Timmia bavarica, also lives in this habitat. Some Mediterranean, sub-Mediterranean, sub-Atlantic species were also found here, like Riccia ciliifera, Didymodon luridus, Entosthodon mublenbergii, Grimmia anodon, Syntrichia handelii, Schistidium brunnescens subsp. griseum, Tortula inermis, Weissia condensa.

\section{Siliceous alpine grasslands}

The siliceous outcrops also maintain a bryophyte assemblage rich in boreal species, e.g. Barbilophozia hatcheri, Lophozia sudetica, L. wenzelii, Coscinodon cribrosus, Grimmia alpestris, Schistidium pruinosum, and in subarctic, subalpine elements as Grimmia anomala, G. caespiticia, Polytrichastrum alpinum, and Tortula hoppeana. As limestone bedrock predominates on the Balkans several calcifuge species can be regarded as rare in this region, like Coscinodon cribrosus, Grimmia anomala, Schistidium pruinosum, which are red-listed in many SE European countries (HodGETTS 2015) and Grimmia caespiticia, a species of European conservation interest (HodGETTS 2015), which is included in the Red data book of European bryophytes (ECCB 1995). A sub-Mediterranean, montane element, Schistidium flaccidum, red-listed in many SE European countries (HodgetTS 2015) can be also mentioned here. 


\section{Shaded limestone rocks}

At lower elevation on shaded limestone, lime containing schistose rocks, and in rocky grasslands besides the predominance of common temperate elements, several Mediterranean, sub-Mediterranean, and sub-Atlantic species occur like Cololejeunea calcarea, Scapania aspera, Campylophyllum calcareum, Cirriphyllum crassinervium, Didymodon luridus, D. vinealis, Homalothecium philippeanum, Leptodon smithii, Neckera menziesii, Plasteurhynchium striatulum, Pterogonium gracile, Seligeria acutifolia, Taxiphyllum wissgrillii, Thamnobryum alopecurum, Tortella humilis, T. nitida, and Tortula atrovirens. Neckera menziesii is a species of European conservation interest (HoDGETTs 2015), while Seligeria acutifolia is rare on the Balkans lacking or being red-listed in many SE European countries (Hodgetrs 2015). Some boreal species also appear, like Leiocolea collaris, Abietinella abietina, Campyliadelphus chrysophyllus, Ditrichum gracile, Encalypta ciliata, Gymnostomum aeruginosum, Mnium stellare, Orthothecium intricatum, Plagiopus oederianus, Pseudoleskeella rupestris, and Tortella tortuosa. Encalypta ciliata is rare on the Balkans, red-listed in some SE European countries (Hodgetts 2015); Pseudoleskeella rupestris is a species of European conservation interest (HodGETTS 2015) and it was reported for the first time in the Republic of Macedonia from this collection (PAPP et al. 2016).

\section{Boreal forests}

In an Abieto-Fagetum forest two red-listed species in Europe were collected: Buxbaumia viridis, a species listed in the Bern Convention and the European Union Habitats and Species Directives and vulnerable in Europe according to the Red data book of European bryophytes (ECCB 1995), was found on decaying wood, while Pseudoleskea saviana, a regionally threatened species according to the Red data book of European bryophytes, was collected from siliceous rock. Both of them are not rare on the Balkans as evidenced by several records. Buxbaumia viridis has many extant populations in the neighbouring Balkan countries such as Serbia (PAPP et al. 2009, 2014), Greece (PAPP et al. 2011, TsAKIRI et al. 2009), and only near threatened (NT) in Bulgaria (NATCHEVA et al. 2006). In the Republic of Macedonia its existing population is known from the Pelister Mts (PAPp and Erzberger 2012). Pseudoleskea saviana has also a lot of known localities in Serbia (PApp et al. 2009, PAPp and Erzberger 2009), Greece, e.g. Voras Mts (PAPP et al. 2011), Albania; e.g. District of Korça (PAPP et al. 2010), Lura region (MARKA and XHulaj 2011), Valbona valley (Papp unpublished), and it is not red-listed in Bulgaria (NATCHEva et al. 2006). In the Republic of Macedonia it is known from the Nidže Mts (PAPP et al. 2011) and Pelister Mts (PAPP and Erzberger 2012). 


\section{Epiphytes}

The epiphyte bryophyte flora living on deciduous trees (Acer monspessulanum L., Betula pendula Roth., Fagus sylvatica L.) is rich. The main constituents are temperate species, e.g. Homalothecium sericeum, Neckera complanata, Orthotrichum affine, Syntrichia ruralis, S. virescens. Several other Orthotrichum species occur, like the subcontinental Orthotrichum obtusifolium and O. speciosum, the sub-Atlantic Orthotrichum lyellii, O. shawii, O. stramineum, O. striatum, and the subboreal Orthotrichum pallens. Orthotrichum shawii is a species of European conservation interest known only from Albania and Greece (HodgetTs 2015), and it was reported for the first time in the Republic of Macedonia from this collection (PAPP et al. 2016).

\section{CONCLUSIONS}

27 bryophyte species ( 7 hepatics and 20 mosses) have been reported recently from this collection for the first time in the Republic of Macedonia (PAPP et al. 2016). These are the following: Athalamia hyalina, Cololejeunea calcarea, C. rossettiana, Conocephalum salebrosum, Jungermannia atrovirens, Lophozia badensis, Scapania calcicola, Brachy thecium tommasinii, Bryum mildeanum, Didymodonspadiceus, Ditrichum gracile, Gyroweisia tenuis, Orthotrichum cupulatum var. riparium, O. shawii, Palustriella falcata, Plagiothecium succulentum, Pseudoleskeella rupestris, Rhynchostegiella curviseta, Schistidium brunnescens subsp. griseum, Seligeria acutifolia, S. pusilla, Syntrichia calcicola, S. handelii, S. subpapillosissima, Taxiphyllum wissgrillii, Tortella fragilis, and T. humilis. The high number of newly recorded species reflects the shortage of knowledge on the Macedonian bryophyte flora and the importance of bryoflora exploration in the region.

The Mavrovo National Park has a rich bryophyte flora due to the geological diversity, high altitudinal range, and climatic variation. Comparing its bryophyte diversity with some other investigated areas nearby in the Republic of Macedonia and in South Serbia, the number of recorded 229 bryophyte taxa is the same as the number of recorded taxa in the Pelister National Park (Republic of Macedonia) (PApp and Erzberger 2012) or in the Kopaonik National Park (Serbia) (PAPP et al. 2004) and more than in Pešter plateau (Serbia) (PAPP et al. 2014) or at Vlasina lake and its surroundings (Serbia) (PAPP et al. 2012). However, more bryophyte taxa (277) were collected in the Golija Biosphere Reserve (Serbia) (PAPP and ERZBERGER 2005).

From conservation point of view the wetlands and rock formations above $1,200 \mathrm{~m}$ have outstanding importance. The wetlands are declining habitat types in SE Europe mainly due to climate warming, their extension is decreasing, and 
they are continuously loosing the sensitive bryophytes of their species pool (Alegro et al. 2014, Ganeva 2015, Natcheva 2015, Papp et al. 2015). The siliceous outcrops have special conservation interest, because being rare on the Balkans, and their bryophyte flora contains many calcifuge species regarded as rare in this region and red-listed in many SE European countries (HodGETTS 2015). However, almost all habitat types of the Mavrovo National Park maintain diverse bryophyte assemblages containing several species rare on the Balkans or even species of European conservation interest. Three species (Buxbaumia viridis, Grimmia caespiticia, and Pseudoleskea saviana) are included in the Red data book of European bryophytes (ECCB 1995). Further eight species (Bryum mildeanum, B. turbinatum, Coscinodon cribrosus, Fontinalis hypnoides, Neckera menziesii, Orthotrichum shawii, Pseudoleskeella rupestris, and Schistidium pruinosum) are on the candidate list of the new Red data book of European bryophytes (HoDGETTS 2015) and ten species (Athalamia hyalina, Leiocolea heterocolpos, Dichodontium palustre, Encalypta ciliata, Grimmia anomala, Palustriella decipiens, Philonotis caespitosa, Plagiomnium ellipticum, Scorpidium cossoni, and Seligeria acutifolia) can be regarded as rare on the Balkans.

Finally, it can be stated that Mavrovo National Park has very valuable bryophyte flora from conservation point of view and we do hope that our investigation can provide useful and important information to the nature conservation.

Összefoglaló: A Mavrovo Nemzeti Parkban 229 mohafajt (34 májmohát és 195 lombosmohát) sikerült kimutatnunk. A park gazdag mohaflórája a változatos alapkőzetnek, a nagy tengerszint feletti magasságkülönbségeknek és a mikroklíma változatosságának köszönhető. Ennek ellenére mohászati felmérés korábban nem történt a területen. Szinte minden vegetációtípusban diverz mohaközösséget találtunk, és számos balkáni vagy akár európai szinten ritka, veszélyeztetett faj fordul elö. Három faj (Buxbaumia viridis, Grimmia caespiticia és Pseudoleskea saviana) szerepel az Európai Moha Vörös Könyvben. További nyolc faj az új Európai Moha Vörös Könyv potenciális vörös listájának tagja, valamint tíz fajt a Balkánon ritkának tartunk. Különösen fontosak természetvédelmi szempontból az 1200 m tengerszint feletti magasságban található vizes, lápos területek, valamint a szilikátszikla-kibukkanások. A lápok veszélyeztetettek a Balkánon főleg a klímaváltozás miatt; folyamatosan veszítenek területükből, fajösszetételük megváltozik, fajdiverzitásuk csökken, a vízellátottság romlására érzékeny fajok eltűnnek. A szilikátos kőzetek ritkák a Balkánon, ahol főleg meszes kőzetek dominálnak, így a savanyú alapkőzethez kapcsolódó mohaközösségek unikálisak a régióban.

\section{REFERENCES}

Alegro, A., Papp, B., Szurdoki, E., Šegota, V., Šapić, I. and Vukelić, J. (2014): Contribution to the bryophyte flora of Croatia III. National Park Plitvička jezera and some adjacent areas. - Studia bot. hung. 45: 49-65. http://dx.doi.org/10.17110/studbot.2014.45.49 
Buzarovs Ki, S. (2009): Mavrovo National Park. - The Youth Ecologists Movement of Macedonia, Skopje, 21 pp.

Cenova, M. (2005): Review of the Bryoflora of the Republic of Macedonia. - PMF, Inst. Biol., Skopje, $42 \mathrm{pp}$.

DüLL, R. (1983): Distribution of the European and Macaronesian liverworts (Hepaticophytina). - Bryol. Beiträge 2: 1-115.

DüLL, R. (1984): Distribution of the European and Macaronesian mosses (Bryophytina) I. - Bryol. Beiträge 4: 1-109.

DüLL, R. (1985): Distribution of the European and Macaronesian mosses (Bryophytina) II. Bryol. Beiträge 5: 110-232.

Düll, R., Ganeva, A., Martinčič, A. and Pavletić, Z. (1999): Contributions to the bryoflora of former Yugoslavia and Bulgaria. - Bryol. Beitr. 11: 1-99.

ECCB (1995): Red data book of European bryophytes. - European Committee for Conservation of Bryophytes, Trondheim, $291 \mathrm{pp.}$

Ganeva, A. (2015): Tomentypnum nitens (Hedw.) Loeske. - In: PeEv, D. (ed.): Red data book of the Republic of Bulgaria, Volume 1. Plants and Fungi. BAS and MoEW, Sofia, p. 108.

Grolle, R. and Long, D. G. (2000): An annotated check-list of the Hepaticae and Anthocerotae of Europe and Macaronesia. - J. Bryol. 22: 103-140. http://dx.doi.org/10.1179/jbr.2000.22.2.103

Hill, M. O., Bell, N., Bruggeman-Nannenga, M. A., Brugués, M., Cano, M. J., Enroth, J., Flatberg, K. I., Frahm, J.-P., Gallego, M. T., Garilleti, R., Guerra, J., Hedenäs, L., Holyoak, D. T., Hyvönen, J., Ignatov, M. S., Lara, F., Mazimpaka, V., Muñoz, J. and SÖDERSTRÖM, L. (2006): An annotated checklist of the mosses of Europe and Macaronesia. - J. Bryol. 28(3): 198-267. http://dx.doi.org/10.1179/174328206X119998

Hodgetts, N. G. (2015): Checklist and country status of European bryophytes - towards a new Red List for Europe. - Irish Wildlife Manuals, No. 84. National Parks and Wildlife Service, Department of Arts, Heritage and the Gaeltacht, Ireland, $125 \mathrm{pp}$.

Kopersi, M., Sauer, M., Braun, W. and Gradstein, S. R. (2000): Referenzliste der Moose Deutschlands. - Schriftenreihe für Vegetationskunde 34: 1-519.

MARKA J. and Xhulaj M. (2011): Mosses from Lura region (Albania). - Int. J. Ecosyst. and Ecol. Sci. 1: 27-30.

MARTINČı ̌́, A. (2009): Contributions to the bryophyte flora of Republic of Macedonia. - Hacquetia 8(2): 97-114. http://dx.doi.org/10.2478/v10028-009-0008-9

NAtcheva, R. (2015): Hamatocaulis vernicosus (Mitt.) Hedenäs, Scorpidium revolvens (Sw.) Hedenäs, Scorpidium scorpioides (Hedw.) Limpr. - In PeEv, D. (ed.): Red Data Book of the Republic of Bulgaria, Volume 1., Plants and Fungi, BAS and MoEW, Sofia, p. 123, 133, 134.

Natcheva, R., Ganeva, A. and Spiridonos, G. (2006): Red list of the bryophytes in Bulgaria. Phytol. Balcan. 12(1): 55-62.

PAPp, B. and ErzBerger, P. (2005): The bryophyte flora of Golija-Studenica Biosphere Reserve and some adjacent sites (SW Serbia, Serbia-Montenegro). - Studia bot. hung. 36: 101-116.

PAPp, B. and ERzBERGER, P. (2009): Contributions to the bryophyte flora of southeastern Serbia: Suva Planina Mts and its surroundings. - Studia bot. hung. 40: 125-142.

PAPp, B. and Erzberger, P. (2012): Contribution to the bryophyte flora of the Former Yugoslav Republic of Macedonia (FYROM). - Polish Bot. J. 57(1): 205-221.

Papp, B., Erzberger, P. and Sabovljević, M. (2004): Contributions to the bryophyte flora of Kopaonik Mts (Serbia, Serbia-Montenegro). - Studia bot. hung. 35: 67-80. 
PAPP, B., ERZBERger, P. and SABovljević, M. (2009): European red-listed bryophyte species collected during the expeditions of the Hungarian Natural History Museum in Serbia between 20002006. - In: Ivanova, D. (ed.): Plant, fungal and habitat diversity investigation and conservation. Proceedings of IV Balkan Botanical Congress, Sofia, 20-26 June 2006. Institute of Botany, Sofia, pp. 541-546.

Papp, B., Erzberger, P. and MARKa, J. (2010): Contributions to the bryophyte flora of eastern Albania (Korça and Kolonja districts). - Studia bot. hung. 41: 61-88.

PAPp, B., Erzberger, P. and Tsakiri, E. (2011): Contributions to the bryophyte flora of the Voras (Nidže) Mts (Greece and the Former Yugoslav Republic of Macedonia). - Studia bot. hung. 42: 51-76.

Papp, B., Szurdoki, E. and Sabovljević, M. (2012): Bryophyte flora of Lake Vlasina and its surroundings (SE Serbia). - Studia bot. hung. 43: 27-45.

Papp, B., Szurdoki, E., Pantović, J. and Sabovljević, M. (2014): Contributions to the bryophyte flora of the Pešter plateau, SW Serbia. - Studia bot. hung. 45: 33-47. http://dx.doi.org/10.17110/StudBot.2014.45.33

PApp, B., SzAKÁLy, Á., and Tóth, Z. (2015): Contributions to the bryophyte flora of the Alcsík basin, Romania. - Studia bot. hung. 46(2): 55-68. http://dx.doi.org/10.17110/StudBot.2015.46.2.55

Papp, B., Pantović, J., Szurdoki, E. and Sabovljević, M. (2016): New bryophyte records for the Republic of Macedonia. - J. Bryol. 38(2): 168-171. http://dx.doi.org/10.1080/03736687.2015.1113628

Ros, R. M., Mazimpaka, V., Abou-Salama, U., Aleffi, M., Blockeel, T. L., Brugués, M., Cano, M. J., Cros, R. M., Dia, M. G., Dirkse, G. M., El SaAdawi, W., ErdaĞ, A., Ganeva, A., González-Mancebo, J. M., Herrnstadt, I., Khalil, K., Kürschner, H., Lanfranco, E., Losada-Lima, A., Refai, M. S., Rodrígez-Nuñez, S., Sabovljević, M., Cérgio, C., Shabbara, H., Sim-Sim, M. and Söderström, L. (2007): Hepatics and Anthocerotes of the Mediterranean, an annotated checklist. - Cryptog. Bryol. 28(4):351-437.

Ros, R. M., Mazimpaka, V., Abou-Salama, U., Aleffi, M., Blockeel, T. L., Brugués, M., Cros, R. M., Dia, M. G., Dirkse, G. M., Draper, I., El SaAdawi, W., ErdaĞ, A., Ganeva, A., Gabriel, R., González-Mancebo, J. M., Granger, C., Herrnstadt, I., Hugonnot, V., Khalil, K., Kürschner, H., Losada-Lima, A., Luís, L., Mifsud, S., Privitera, M., Puglisi, M., Sabovljević, M., Sérgio, C., Shabbara, H. M., Sim-Sim, M., Sotiaux, A., Tacchi, R., Vanderpoorten, A. and Werner, O. (2013): Mosses of the Mediterranean, an annotated checklist. - Cryptog. Bryol. 34(2): 99-283.

http://dx.doi.org/doi/ 10.782/cryb.v34.iss2.2013.99

SABovljević, M. and Natcheva, R. (2006): A check-list of the liverworts and hornworts of Southeast Europe. - Phytol. Balcan. 12: 169-180.

Sabovljević, M., Ganeva, A., Tsakiri, E. and ŞTefănUț, S. (2001): Bryology and bryophyte protection in the southeastern Europe. - Biol. Cons. 101: 73-84.

Sabovljević M., Natcheva R., Tsakiri E., Dihoru G., Dragićević S., ErdaĞ A. and Papp, B. (2008): Check-list of the mosses of SE Europe. - Phytol. Balcan. 14: 207-244.

Sabovljević, M., Alegro, A., Sabovljević, A., Marka, J. and Vujičić, M. (2011): An insight into diversity of the Balkan Peninsula bryophyte flora in the European background. - Rev. d'Ecol. (Terre et Vie) 66:399-413.

SzWeykowski, J., Buczkowska, K. and Odrzykoski, I. J. (2005): Conocephalum salebrosum (Marchantiopsida, Conocephalaceae) - a new Holarctic liverwort species. - Pl. Syst. Evol. 253: 133-158. http://dx.doi.org/10.1007/s00606-005-0301-0 
Tsakiri, E., Papp, B. and Blockeel, T. (2009): Buxbaumia viridis (Moug. ex Lam. \& DC.) Brid. ex Moug. \& Nestl. - In Foitos, D., Konstantinidis, Th. and Kamari, G. (eds.): Vivlio erythron dedomenon ton spanion kai apeiloumenon fyton tis Elladas (The Red Data Book of rare and threatened plants of Greece), Hellenic Botanical Society, Patras, Vol. 1, pp. 166-168.

(submitted: 15.01 .2016 , accepted 30.06.2016)

\section{Appendix 1. Complete list of bryophyte records.}

The numerals following the species names refer to the collection sites described above.

\section{Hepaticae}

Athalamia hyalina (Sommerf.) S. Hatt. - 2, 5: limestone rock; 11: exposed schistose rock Barbilophozia barbata (Schreb.) Loeske - 10: limestone rock

Barbilophozia hatcheri (A. Evans) Loeske - 11: exposed schistose rock; 14: exposed siliceous rock Barbilophozia lycopodioides (Wallr.) Loeske - 2, 5: limestone rock; 4: soil among schistose rock Cephaloziella divaricata (Sm.) Schiffn. - 1, 11: schistose rock; 5: limestone rock Chiloscyphus polyanthus (L.) Corda - 11: wet meadows along a stream

Cololejeunea calcarea (Lib.) Schiffn. - 9: shaded limestone rock

Cololejeunea rossettiana (C. Massal.) Schiffn. - 8: wet limestone rock

Conocephalum salebrosum Szweykowski, Buczkowska et Odrzykoski - 9: along the river; 16: limestone rock at the stream

Frullania dilatata (L.) Dumort. - 9: bark Alnus; 15: schistose rock and bark of Prunus avium

Jungermannia atrovirens Dumort. - 6: at a rivulet; 16: limestone rock at the stream

Leiocolea badensis (Gottsche) Jörg. - 6: at a rivulet; 7: limestone grassland

Leiocolea collaris (Nees) Schljakov - 15: schistose rock; 16: limestone rock at the stream

Leiocolea heterocolpos (Hartm.) H. Buch - 5: limestone rock

Lophocolea heterophylla (Schrad.) Dumort. - 10: limestone rock and decaying wood

Lophocolea minor Nees - 4: limestone grassland

Lophozia sudetica (Nees ex Huebener) Grolle - 11: exposed schistose rock

Lophozia wenzelii (Nees) Steph. - 11: exposed schistose rock

Marchantia polymorpha L. - 1: wet schistose rock

Marsupella funckii (F. Weber et D. Mohr) Dumort. - 11: exposed schistose rock

Metzgeria furcata (L.) Dumort. - 10: limestone, siliceous rock, and decaying wood

Pedinophyllum interruptum (Nees) Kaal. - 5: limestone rock

Pellia endiviifolia (Dicks.) Dumort. - 1: wet schistose rock; 6, 10: at a rivulet; 8: wet limestone rock; 16: limestone rock at the stream

Plagiochila porelloides (Torrey ex Nees) Lindenb. - 2, 5, 10: limestone rock; 9: along the river; 16: limestone rock at the stream

Porella cordaeana (Huebener) Mohr - 2, 10: limestone rock; 4: limestone grassland; 14: exposed siliceous rock

Preissia quadrata (Scop.) Nees - 2: limestone rock; 16: limestone rock at the stream

Radula complanata (L.) Dumort. - 7: limestone grassland; 9: bark Alnus; 15: tree bark

Reboulia hemisphaerica (L.) Raddi - 2, 5: limestone rock; 10: siliceous rock

Riccia ciliifera Link ex Lindenb. - 2: limestone rock

Riccia sorocarpa Bisch. -5 : limestone rock 
Riccia sorocarpa Bisch. var. heegii Schiffn. - 2: limestone rock Scapania aspera M. Bernet et Bernet - 16: limestone rock Scapania calcicola (Arnell et J. Perss.) Ingham - 2, 5: limestone rock Scapania irrigua (Nees) Nees - 2: wetland

\section{Musci}

Abietinella abietina (Hedw.) M. Fleisch. - 6: limestone rock Amphidium mougeotii (Schimp.) Schimp. - 10: siliceous rock

Anomodon viticulosus (Hedw.) Hook. et Taylor - 6, 8: limestone rock; 8: bark of Acer; 15: schistose rock

Aulacomnium palustre (Hedw.) Schwägr. - 2: wetland

Barbula convoluta Hedw. - 1: concrete wall; 5, 12: limestone rock

Barbula unguiculata Hedw. - 1: schistose rock; 2, 6: limestone rock; 3: limestone rockwall; 4: limestone grassland

Bartramia ithyphylla Brid. - 4: soil among schistose rock; 11: exposed schistose rock

Brachytheciastrum velutinum (Hedw.) Ignatov et Huttunen - 2: edge of wet meadow; 3: limestone rockwall; 4: limestone grassland; 6: limestone rock, 10: limestone, siliceous rock, and decaying wood; 11: exposed schistose rock

Brachythecium albicans (Hedw.) Schimp. - 1: soil

Brachythecium glareosum (Bruch ex Spruce) Schimp. - 4: limestone grassland; 5, 10, 12: limestone rock; 8: shaded limestone rock; 11: exposed schistose rock

Brachythecium rivulare Schimp. - 1: wet schistose rock; 2: wetland; 11: wet meadows along a stream

Brachythecium rutabulum (Hedw.) Schimp. - 6, 16: limestone rock; 8: shaded limestone rock; 9: along the river; 10 : siliceous rock

Brachythecium salebrosum (Hoffm. ex F. Weber et D. Mohr) Schimp. - 2: edge of wet meadow

Brachythecium tommasinii (Sendtn. ex Boulay) Ignatov et Huttunen - 8, 9: shaded limestone rock

Bryoerythrophyllum recurvirostrum (Hedw.) P. C. Chen - 5, 6, 10: limestone rock; 14: schistose rock

Bryum alpinum Huds. ex With. - 1: schistose rock; 11: wet meadows along a stream and exposed schistose rock

Bryum argenteum Hedw. - 1: schistose rock; 3: limestone rockwall

Bryum caespiticium Hedw. - 1: soil; 2: limestone rock; 7: limestone grassland

Bryum capillare Hedw. - 7: limestone grassland; 8: shaded limestone rock; 10, 16: limestone rock Bryum dichotomum Hedw. - 1: schistose rock; 15: schistose rock

Bryum elegans Nees - 12: limestone rock

Bryum mildeanum Jur. - 3: siliceous rock of an artificial wall

Bryum moravicum Podp. - 6: limestone rock; 10: siliceous rock

Bryum pallescens Schleich. ex Schwägr. - 4: limestone grassland; 11: exposed schistose rock

Bryum pseudotriquetrum (Hedw.) P. Gaertn. et al. - 2: wetland

Bryum schleicheri DC. - 2: wetland; 11: wet meadows along a stream

Bryum turbinatum (Hedw.) Turner - 1: wet schistose rock; 2: wetland

Buxbaumia viridis (Moug. ex Lam. et DC.) Brid. ex Moug. et Nestl. - 10: decaying wood

Calliergon cordifolium (Hedw.) Kindb. - 11: wet meadows along a stream

Calliergonella cuspidata (Hedw.) Loeske - 2: wetland; 10: along a rivulet; 11: wet meadows along a stream

Campyliadelphus chrysophyllus (Brid.) R. S. Chopra - 6: limestone rock 
Campylium protensum (Brid.) Kindb. - 16: limestone rock at the stream

Campylium stellatum (Hedw.) Lange et C. E. O. Jensen - 11: wet meadows along a stream

Campylophyllum calcareum (Crundw. et Nyholm) Hedenäs - 9: shaded limestone rock; 10: limestone rock; 15: schistose rock

Ceratodon purpureus (Hedw.) Brid. - 1: schistose rock and soil

Cinclidotus fontinaloides (Hedw.) P. Beauv. - 9: along the river and bark Alnus

Cirriphyllum crassinervium (Taylor) Loeske et M. Fleisch. - 8, 16: shaded limestone rock; 9: along the river

Climacium dendroides (Hedw.) F. Weber et D. Mohr - 2: wetland

Coscinodon cribrosus (Hedw.) Spruce - 1: schistose rock

Cratoneuron filicinum (Hedw.) Spruce - 1: wet schistose rock; 6, 10: at a rivulet; 11: wet meadows along a stream; 16: limestone rock at the stream

Ctenidium molluscum (Hedw.) Mitt. - 5: limestone rock; 8, 16: shaded limestone rock

Dichodontium palustre (Dicks.) M. Stech - 11: wet meadows along a stream

Dichodontium pellucidum (Hedw.) Schimp. - 11: schistose rock in the stream

Dicranella rufescens (Dicks.) Schimp. - 1: schistose rock, 8: wet limestone rock

Dicranella varia (Hedw.) Schimp. - 7: limestone grassland; 8: wet limestone rock

Dicranum scoparium Hedw. - 8: shaded limestone rock; 14: exposed siliceous rock

Didymodon fallax (Hedw.) R. H. Zander - 5: limestone rock; 6: at a rivulet; 7: limestone grassland

Didymodon insulanus (De Not.) M. O. Hill - 1: schistose rock

Didymodon luridus Hornsch. - 4: limestone grassland; 6: limestone rock

Didymodon rigidulus Hedw. - 1: concrete wall; 6, 13: limestone rock; 8: wet limestone rock

Didymodon sinuosus (Mitt.) Delogne - 9: along the river

Didymodon spadiceus (Mitt.) Limpr. - 8: wet limestone rock; 16: limestone rock at the stream

Didymodon vinealis (Brid.) R. H. Zander - 8: shaded limestone rock; 16: limestone rock at the stream

Distichium capillaceum (Hedw.) Bruch et Schimp. - 2, 5, 10, 12: limestone rock; 7: limestone grassland

Ditrichum flexicaule (Schwägr.) Hampe - 2, 5, 10: limestone rock; 7: limestone grassland; 9: shaded limestone rock

Ditrichum gracile (Mitt.) Kuntze - 8: shaded limestone rock; 12: limestone rock

Ditrichum pusillum (Hedw.) Hampe - 1: schistose rock

Drepanocladus aduncus (Hedw.) Warnst. - 2: wetland

Encalypta ciliata Hedw. - 15: schistose rock

Encalypta rhaptocarpa Schwägr. - 12: limestone rock

Encalypta streptocarpa Hedw. - 5, 6: limestone rock; 8: shaded limestone rock

Entosthodon mublenbergii (Turner) Fife - 2, 5: limestone rock

Eucladium verticillatum (With.) Bruch et Schimp. - 8: wet limestone rock

Eurhynchiastrum pulchellum (Hedw.) Ignatov et Huttunen - 2, 5: limestone rock; 4: limestone grassland; 10: siliceous rock; 11: exposed schistose rock

Eurhynchium angustirete (Broth.) T. J. Kop. - 10: limestone rock

Fissidens bryoides Hedw. - 4: limestone grassland; 15: schistose rock

Fissidens dubius P. Beauv. - 16: limestone rock

Fissidens taxifolius Hedw. - 6: at a rivulet; 16: limestone rock at the stream

Fontinalis hypnoides $\mathrm{C}$. Hartm. - 11: wet meadows along a stream

Grimmia alpestris (F. Weber et D. Mohr) Schleich. - 2: schistose rock

Grimmia anodon Bruch et Schimp. - 12: limestone rock

Grimmia anomala Hampe ex Schimp. - 11: exposed schistose rock; 14: exposed siliceous rock 
Grimmia caespiticia (Brid.) Jur. - 11: exposed schistose rock; 14: exposed siliceous rock

Grimmia laevigata (Brid.) Brid. - 15: schistose rock

Grimmia montana Bruch et Schimp. - 11: exposed schistose rock

Grimmia mueblenbeckii Schimp. - 14: exposed siliceous rock

Grimmia ovalis (Hedw.) Lindb. - 1, 11, 15: schistose rock; 14: exposed siliceous rock

Grimmia pulvinata (Hedw.) Sm. - 1: concrete wall; 3: limestone rockwall; 15: schistose rock

Gymnostomum aeruginosum Sm. - 8, 9: shaded limestone rock; 16: limestone rock at the stream

Gymnostomum calcareum Nees et Hornsch. - 8: wet limestone rock

Gyroweisia tenuis (Hedw.) Schimp. - 8: wet limestone rock

Herzogiella seligeri (Brid.) Z. Iwats. - 10: decaying wood

Homalothecium lutescens (Hedw.) H. Rob. - 1: soil

Homalothecium philippeanum (Spruce) Schimp. - 2, 13: limestone rock; 8: shaded limestone rock

Homalothecium sericeum (Hedw.) Schimp. - 1: concrete wall; 3: limestone rockwall; 6, 12, 16: limestone rock; 8: bark of Acer; 15: bark of Acer monspessulanum

Homomallium incurvatum (Schrad. ex Brid.) Loeske - 8: shaded limestone rock

Hygrohypnum luridum (Hedw.) Jenn. - 6: at a rivulet; 8: wet limestone rock; 9: along the river; 16: limestone rock at the stream

Hylocomium splendens (Hedw.) Schimp. - 8: shaded limestone rock; 16: soil

Hypnum cupressiforme Hedw. - 7: limestone grassland; 9: shaded limestone rock; 10: limestone rock; 15: schistose rock

Isothecium alopecuroides (Lam. ex Dubois) Isov. - 10: siliceous rock and decaying wood; 14: exposed siliceous rock

Leptodon smithii (Hedw.) F. Weber et D. Mohr - 16: limestone rock

Leucodon sciuroides (Hedw.) Schwägr. - 8: shaded limestone rock and bark of Acer; 15: schistose rock

Mnium marginatum (Dicks.) P. Beauv. - 6: limestone rock

Mnium stellare Hedw. - 4: limestone grassland; 5, 6: limestone rock; 8: shaded limestone rock; 10: limestone rock and along a rivulet

Neckera besseri (Lobarz.) Jur. $-8,16$ : shaded limestone rock

Neckera complanata (Hedw.) Huebener - 6, 16: limestone rock; 8: bark of Acer; 15: bark of Acer monspessulanum

Neckera crispa Hedw. - 16: limestone rock

Neckera menziesii Drumm. - 8: shaded limestone rock; 10: siliceous rock

Orthothecium intricatum (Hartm.) Schimp. - 8: shaded limestone rock

Orthotrichum affine Schrad. ex Brid. - 8: bark of Fagus; 9: bark of Alnus; 10: Abies branch; 15: bark of Acer monspessulanum and Prunus avium; 18: bark of Fagus and Betula pendula

Orthotrichum anomalum Hedw. - 3: limestone rockwall; 15: schistose rock; 16: limestone rock

Orthotrichum cupulatum Hoffm. ex Brid. var. cupulatum - 2, 11, 12, 16: limestone rock; 3: limestone rockwall

Orthotrichum cupulatum Hoffm. ex Brid. var. riparium Huebener - 9: along the river

Orthotrichum diaphanum Schrad. ex Brid. - 17: bark of Robinia pseudo-acacia

Orthotrichum lyellii Hook. et Taylor - 15: bark of Prunus avium

Orthotrichum obtusifolium Brid. - 15: bark of Acer monspessulanum; 17: bark of Robinia pseudoacacia

Orthotrichum pallens Bruch ex Brid. - 18: bark of Fagus

Orthotrichum pumilum Sw. ex anon. - 1: schistose rock; 17: bark of Robinia pseudo-acacia

Orthotrichum shawii Wilson - 18: bark of Betula pendula 
Orthotrichum speciosum Nees - 8: bark of Fagus; 10: Abies branch; 18: bark of Fagus and Betula pendula

Orthotrichum stramineum Hornsch. ex Brid. - 9: bark of Alnus; 15: bark of Acer monspessulanum; 18: bark of Fagus and Betula pendula

Orthotrichum striatum Hedw. - 1: schistose rock; 8: bark of Fagus; 9: bark of Alnus and Prunus avium; 18: bark of Fagus and Betula pendula

Oxyrrhynchium hians (Hedw.) Loeske - 6: limestone rock; 8, 16: shaded limestone rock

Palustriella commutata (Hedw.) Ochyra - 6: at a rivulet; 8: wet limestone rock; 16: limestone rock at the stream

Palustriella decipiens (De Not.) Ochyra - 1: wet schistose rock; 2: wetland; 11: wet meadows along a stream

Palustriella falcata (Brid.) Hedenäs - 11: wet meadows along a stream

Philonotis caespitosa Jur. - 2: wetland

Philonotis fontana (Hedw.) Brid. - 1: wet schistose rock; 11: wet meadows along a stream

Philonotis seriata Mitt. - 1: wet schistose rock; 2: wetland

Plagiomnium affine (Blandow ex Funck) T. J. Kop. - 4: limestone grassland and soil among schistose rock; 8, 16: shaded limestone rock

Plagiomnium cuspidatum (Hedw.) T. J. Kop. - 8: shaded limestone rock

Plagiomnium elatum (Bruch et Schimp.) T. J. Kop. - 11: wet meadows along a stream

Plagiomnium ellipticum (Brid.) T. J. Kop. - 2: wetland; 11: wet meadows along a stream

Plagiomnium rostratum (Schrad.) T. J. Kop. - 6, 12: limestone rock; 8: shaded limestone rock; 9: along the river

Plagiomnium undulatum (Hedw.) T. J. Kop. - 4: soil among schistose rock; 16: limestone rock at the stream

Plagiopus oederianus (Sw.) H. A. Crum et L. E. Anderson - 6: limestone rock; 8: shaded limestone rock

Plagiothecium cavifolium (Brid.) Z. Iwats. - 14: exposed siliceous rock

Plagiothecium succulentum (Wilson) Lindb. - 10: siliceous rock

Plasteurbynchium striatulum (Spruce) M. Fleisch. - 8, 16: shaded limestone rock; 15: schistose rock

Platyhypnidium riparioides (Hedw.) Dixon - 6: at a rivulet; 11: wet meadows along a stream; 16: limestone rock at the stream

Pleurochaete squarrosa (Brid.) Lindb. - 15: schistose rock

Pogonatum aloides (Hedw.) P. Beauv. - 10: soil along the road

Pohlia andalusica (Höhn.) Broth. - 2: wetland

Poblia annotina (Hedw.) Lindb. - 1: schistose rock

Pohlia cruda (Hedw.) Lindb. - 11: exposed schistose rock

Poblia melanodon (Brid.) A. J. Shaw - 1: wet schistose rock; 4: limestone grassland; 8: wet limestone rock; 10: limestone rock

Pohlia wablenbergii (F. Weber et D. Mohr) A. L. Andrews - 4: limestone grassland; 6, 10: at a rivulet; 15: schistose rock

Polytrichastrum alpinum (Hedw.) G. L. Sm. - 1, 11: schistose rock; 4: soil among schistose rock

Polytrichum commune Hedw. - 2: wetland

Polytrichum commune Hedw. var. perigoniale (Michx.) Hampe - 2: wetland

Polytrichum juniperinum Hedw. - 2, 5: limestone rock; 11: exposed schistose rock

Polytrichum piliferum Hedw. - 1: schistose rock; 14: exposed siliceous rock

Pseudocrossidium hornschuchianum (Schultz) R. H. Zander - 7: limestone grassland

Pseudoleskea incurvata (Hedw.) Loeske - 2, 5, 12: limestone rock; 14: exposed siliceous rock 
Pseudoleskea saviana (De Not.) Latzel - 10: siliceous rock

Pseudoleskeella catenulata (Brid. ex Schrad.) Kindb. - 13: exposed limestone rock

Pseudoleskeella rupestris (Berggr.) Hedenäs et L. Söderstr. - 9: shaded limestone rock

Pseudoscleropodium purum (Hedw.) M. Fleisch. - 16: soil

Pterigynandrum filiforme Hedw. - 9: bark of Alnus; 10: decaying wood; 14: exposed siliceous rock; 15: bark of Prunus avium

Pterogonium gracile (Hedw.) Sm. - 15: schistose rock

Pterygoneurum ovatum (Hedw.) Dixon - 7: limestone grassland

Ptychodium plicatum (Schleich. ex F. Weber et D. Mohr) Schimp. - 2: limestone rock

Racomitrium canescens (Hedw.) Brid. - 1: soil; 2: limestone rock

Racomitrium elongatum Ehrh. ex Frisvoll - 4, 11: soil among schistose rock

Rhizomnium punctatum (Hedw.) T. J. Kop. - 10: along a rivulet; 11: wet meadows along a stream Rhynchostegiella curviseta (Brid.) Limpr. - 16: limestone rock at the stream

Rhytidiadelphus triquetrus (Hedw.) Warnst. - 10: limestone rock

Sanionia uncinata (Hedw.) Loeske - 2: limestone rock; 4: soil among schistose rock

Schistidium apocarpum (Hedw.) Bruch et Schimp. - 1: schistose rock

Schistidium brunnescens Hedw. subsp. griseum (Nees et Hornsch.) H. H. Blom - 1: concrete wall;

2, 13: limestone rock

Schistidium confertum (Funck) Bruch et Schimp. - 14: exposed siliceous rock

Schistidium crassipilum H. H. Blom - 6, 16: limestone rock; 9: along the river; 15: schistose rock

Schistidium flaccidum (De Not.) Ochyra - 1, 2, 15: schistose rock

Schistidium helveticum (Schkuhr) Deguchi - 11: limestone rock

Schistidium pruinosum (Wilson ex Schimp.) G. Roth - 11: exposed schistose rock; 14: exposed siliceous rock

Sciuro-hypnum populeum (Hedw.) Ignatov et Huttunen - 10: siliceous rock

Scorpidium cossonii (Schimp.) Hedenäs - 11: wet meadows along a stream

Seligeria acutifolia Lindb. - 16: limestone rock at the stream

Seligeria pusilla (Hedw.) Bruch et Schimp. - 6: limestone rock

Syntrichia calcicola J. J. Amann - 1: concrete wall

Syntrichia handelii (Schiffn.) S. Agnew et Vondr. - 11, 12: limestone rock

Syntrichia norvegica F. Weber - 5: limestone rock; 14: exposed siliceous rock

Syntrichia papillosa (Wilson) Jur. - 17: bark of Robinia pseudo-acacia

Syntrichia ruralis (Hedw.) F. Weber et D. Mohr - 1: soil; 2, 5: limestone rock; 3: limestone rockwall; 7: limestone grassland; 10: limestone and siliceous rock; 11: schistose rock; 15: schistose rock and bark of Acer monspessulanum; 17: bark of Robinia pseudo-acacia

Syntrichia subpapillosissima (Bizot et R. B. Pierrot ex W. A. Kramer) M. T. Gallego et J. Guerra 14: exposed siliceous rock

Syntrichia virescens (De Not.) Ochyra - 15: bark of Acer monspessulanum

Taxiphyllum wissgrillii (Garov.) Wijk et Margad. - 8: shaded limestone rock

Thamnobryum alopecurum (Hedw.) Gangulee - 8, 16: shaded limestone rock

Timmia bavarica Hessl. - 2, 5: limestone rock

Tortella fragilis (Hook. et Wilson) Limpr. - 7: limestone grassland

Tortella bumilis (Hedw.) Jenn. - 15: schistose rock

Tortella inclinata (R. Hedw.) Limpr. - 7: limestone grassland

Tortella nitida (Lindb.) Broth. - 9: shaded limestone rock

Tortella tortuosa (Hedw.) Limpr. - 2, 5, 12, 16: limestone rock; 7: limestone grassland; 8, 9: shaded limestone rock

Tortula atrovirens $(\mathrm{Sm}$.$) Lindb. - 15: schistose rock$ 
Tortula hoppeana (Schultz) Ochyra - 11: exposed schistose rock; 14: exposed siliceous rock Tortula inermis (Brid.) Mont. - 3: limestone rockwall; 4: limestone grassland Tortula modica R. H. Zander - 3: limestone rockwall

Tortula muralis Hedw. - 3: limestone rockwall

Tortula subulata Hedw. - 3: limestone rockwall; 11, 15: schistose rock

Trichostomum crispulum Bruch - 7: limestone grassland; 15: schistose rock

Warnstorfia exannulata (Schimp.) Loeske - 2: wetland; 11: wet meadows along a stream

Weissia condensa (Voit) Lindb. - 4: limestone grassland; 5, 12: limestone rock

Weissia controversa Hedw. - 1, 15: schistose rock

Zygodon rupestris Schimp. ex Lorentz - 15: schistose rock 